\title{
OPEN Publisher Correction: The genetic legacy of extreme exploitation in a polar vertebrate
}

\section{Anneke J. Paijmans, Martin A. Stoffel, Marthán N. Bester, Alison C. Cleary, P. J. Nico De Bruyn, Jaume Forcada, Michael E. Goebel, Simon D. Goldsworthy, Christophe Guinet, Christian Lydersen, Kit M. Kovacs, Andrew Lowther \& Joseph I. Hoffman}

Correction to: Scientific Reports https://doi.org/10.1038/s41598-020-61560-8, published online 20 March 2020

The original version of this Article contained errors.

As a result of a typesetting error, in the original PDF version of the Article Affiliation 5 was incorrectly listed as 'Present address: Department of Natural Sciences, University of Agder, 4630, Kristiansand, Norway.. The correct affiliation is listed below:

Department of Natural Sciences, University of Agder, 4630, Kristiansand, Norway.

Additionally, in the original HTML version of this Article, Michael E. Goebel was incorrectly affiliated with 'South Australian Research and Development Institute, 2 Hamra Avenue, West Beach, South Australia, 5024, Australia. The correct affiliations are listed below:

Antarctic Ecosystem Research Division, Southwest Fisheries Science Center, National Marine Fisheries, National Oceanographic and Atmospheric Administration, 8901 La Jolla Shores Drive, La Jolla, CA, 92037, USA.

Present address: Institute of Marine Science, University of California Santa Cruz, 1156 High Street, Santa Cruz, CA, 95064, USA.

These errors have now been corrected in the HTML and PDF versions of this Article.

(i) Open Access This article is licensed under a Creative Commons Attribution 4.0 International License, which permits use, sharing, adaptation, distribution and reproduction in any medium or format, as long as you give appropriate credit to the original author(s) and the source, provide a link to the Creative Commons license, and indicate if changes were made. The images or other third party material in this article are included in the article's Creative Commons license, unless indicated otherwise in a credit line to the material. If material is not included in the article's Creative Commons license and your intended use is not permitted by statutory regulation or exceeds the permitted use, you will need to obtain permission directly from the copyright holder. To view a copy of this license, visit http://creativecommons.org/licenses/by/4.0/.

(c) The Author(s) 2020 